\title{
Epigenetic mechanisms in Alzheimer's disease [Corrigendum]
}

\section{Balazs R. Degenerative Neurological and Neuromuscular}

Disease. 2014;4:85-102.

On page 86, in the right column, on line 9 from the bottom,

"L1" should be corrected to "L10a".

\section{Publish your work in this journal}

Degenerative Neurological and Neuromuscular Disease is an international, peer-reviewed, open access journal focusing on research into degenerative neurological and neuromuscular disease, identification of therapeutic targets and the optimal use of preventative and integrated treatment interventions to achieve improved outcomes, enhanced

survival and quality of life for the patient. The manuscript management system is completely online and includes a very quick and fair peer-review system. Visit http://www.dovepress.com/testimonials.php to read real quotes from published authors.

submit your manuscript $\mid$ www.dovepress.com

Dovepress

http://dx.doi.org/1 0.2147/DNND.S72448 